\title{
Geostrophic Transport in the Benguela Current Region
}

\author{
Lothar Stramma and Ray G. Peterson \\ Institut für Meereskunde an der Universität Kiel, Kiel, Federal Republic of Germany
}

(Manuscript received 23 November 1988, in final form 3 April 1989)

\begin{abstract}
. Historical data from the region between the Greenwich meridian and the African continental shelf are used to compute the offshore geostrophic transport of the Benguela Current. At $32^{\circ} \mathrm{S}$, the Benguela Current is located near the African coast, transporting about $21 \mathrm{~Sv}\left(1 \mathrm{~Sv}=10^{6} \mathrm{~m}^{3} \mathrm{~s}^{-1}\right)$ of surface water toward the north relative to a potential density surface lying between the upper branch of Circumpolar Deep Water and the North Atlantic Deep Water. Two warm core eddies of probable Agulhas Current origin are observed west of the Benguela Current at $32^{\circ} \mathrm{S}$. Near $30^{\circ} \mathrm{S}$, the Benguela Current turns toward the northwest and begins to separate from the eastern boundary. It carries about $18 \mathrm{~Sv}$ of surface water across $28^{\circ} \mathrm{S}$. The current then turns mainly toward the west to flow over a relatively deep segment of the Walvis Ridge south of the Valdivia Bank. A surface current with northward speeds of about $10 \mathrm{~cm} \mathrm{~s}^{-1}$ flows along the western side of the Valdivia Bank, while another northward surface current flows at about $20 \mathrm{~cm} \mathrm{~s}^{-1}$ some $300 \mathrm{~km}$ west of the bank. About 3 Sv of surface flow do not leave the Cape Basin south of the Valdivia Bank, but instead drift northward as a wide, sluggish flow out of the northern end of the Cape Basin. Because of the more southerly seaward extensions of most of the Benguela Current, there are no deep-reaching interactions observed between this current and the cyclonic gyre in the Angola Basin east of the Greenwich meridian. Beneath the surface layer, about 4-5 Sv of Antarctic Intermediate Water are carried northward across $32^{\circ}$ and $28^{\circ} \mathrm{S}$ by the Benguela Current, essentially all of which turns westward to cross the Greenwich meridian south of $24^{\circ} \mathrm{S}$.
\end{abstract}

\section{Introduction}

In his classic work, Rennell (1832) described the "Lagullas Current" as rounding the southern tip of Africa to feed Indian Ocean water into the northwardflowing "South Atlantic Current," water that would ultimately find its way into the Gulf Stream system. Not long after, charts appeared by Berghaus (1852) depicting much of the Agulhas Current as turning back to the Indian Ocean at the southern end of Africa, these being among the earliest depictions of the Agulhas Current Retroflection. Charts from the following decade (Petermann 1865; Berghaus 1867) show the Agulhas Retroflection as being complete, with the northward flow in the eastern South Atlantic as being composed of waters from the subtropical gyre and, erroneously, from Antarctic origins. This view of the Benguela Current with Antarctic influx was accepted by Krümmel (1882) on the basis of recent British charts (no citations given), and by others well into the 20 th century. Seasonal upwelling of cold water off the western coast of southern Africa, as inferred by Witte (1880), Buchan (1895), and Schott (1902), was instrumental in shaping that early view.

Corresponding author address: Dr. Lothar Stramma, Institut für Meereskunde an der Universität Kiel, Abteilung Meerephysik, Düsternbrooker Weg 20, 2300 Kiel, Federal Republic of Germany.
Atmospheric conditions in the Benguela Current region are influenced mainly by a semi-permanent high pressure system over the subtropical South Atlantic and by a low pressure system that develops over southern Africa during the austral summer. The prevailing winds in the region are thus from the south and southeast, which in turn drive an offshore surface drift and coastal upwelling of cool, nutrient-rich water. This upwelling exists, with much spatial and temporal variability, all along the southwestern coast of Africa from Cape Point $\left(34.35^{\circ} \mathrm{S}\right)$ to Cape Frio $\left(18.4^{\circ} \mathrm{S}\right)$, supporting one of the world's richest fisheries. North of Cape Frio, in the Angola Basin, is a cyclonic circulation capable of producing southward geostrophic currents exceeding $50 \mathrm{~cm} \mathrm{~s}^{-1}$ along the Angola coast (Moroshkin et al. 1970). In the southern portions of the upwelling regime, on the continental shelf near Cape Town, Bang and Andrews (1974) observed a frontal jet having northward velocities of more than $1.2 \mathrm{~m} \mathrm{~s}^{-1}$ and a volume transport of $7 \mathrm{~Sv}$ ( 1 sverdrup $=10^{6}$ $\mathrm{m}^{3} \mathrm{~s}^{-1}$ ).

The economically important upwelling along the southwestern coast of Africa has attracted much attention (for reviews see Nelson and Hutchings 1983; Shannon 1985; Chapman and Shannon 1985). However, with the many detailed studies there has come an inconsistency in what the term "Benguela Current" stands for. Hart and Currie (1960) applied the term to only the region of cool upwelled water along the 
coast, calling the adjacent flow of subtropical water the Southeast Trade Wind Drift. Similar use of Benguela Current can be found in papers such as Darbyshire (1963), Stander (1964), Shannon (1966), Shannon and van Rijswijck (1969), and Nelson and Hutchings (1983). Lately, however, Lutjeharms and Stockton (1987) and Lutjeharms and Valentine (1987) have left out the term Benguela Current in descriptions of the coastal upwelling, referring to that instead as simply being the upwelling regime off southwestern Africa.

Using a two-layer global model, Veronis (1973) concluded that eastern boundary currents are required for geostrophically balanced circulation and set the stage for the intense upwelling often observed, as opposed to being due to local alongshore winds. But he also observed the Benguela Current as serving a different function; it exists at least in part because of the abrupt adjustment of the thermocline depth at the latitude where subtropical and denser waters meet, giving rise to a flow (almost a source flow) that can be suffciently intense for inertial processes to be important. Here we adopt the large-scale, and probably more widespread, view of the Benguela Current being the eastern boundary current of the South Atlantic subtropical gyre.

As compared with upwelling processes along the southwestern coast of Africa, the offshore portion of the Benguela Current has received little attention. Using data from the Meteor expedition at $28^{\circ} \mathrm{S}$, Sverdrup et al. (1942) estimated the transport of this current as being $16 \mathrm{~Sv}$. From the same section, a northward transport of $18.7 \mathrm{~Sv}$ in the upper $600 \mathrm{~m}$ in the eastern basin (east of $13^{\circ} \mathrm{W}$ ) can be extracted from Table 17 in Wüst (1957). Again using these Meteor data plus an inshore station at $25^{\circ} \mathrm{S}$, Wooster and Reid (1963) calculated a Benguela Current transport of about 15 Sv relative to $1000 \mathrm{db}$. Applying inverse techniques on the Meteor and IGY (International Geophysical Year) data, Fu (1981) derived a field of geostrophic transport showing the Benguela Current as carrying about $20 \mathrm{Mt}$ $\mathrm{s}^{-1}$ of surface water across $32^{\circ} \mathrm{S}$, whereupon the current widens considerably toward the northwest. As far as we are aware, these are the only deep-water estimates for the transport of the Benguela Current.

In the region of what can be called the source of the Benguela Current, i.e., west of the Cape of Good Hope, eddies detatched from the Agulhas Retroflection can often be found. According to a census of satellite infrared images (Lutjeharms and van Ballegooyen 1988), the Agulhas Retroflection attains its greatest penetrations into the South Atlantic an average of nine times per year, with each event followed by the shedding of a warm core eddy that typically drifts away toward the west at $12 \mathrm{~cm} \mathrm{~s}^{-1}$. Altimetric data from GEOSAT, however, reveal a slower production rate of Agulhas rings, only 3 to 4 per year, and a slower mean drift of $5-7 \mathrm{~cm} \mathrm{~s}^{-1}$ toward the northwest (Gordon and Haxby 1988). One of these has recently been observed with shipboard observations in the process of detatching from the retroflection loop (Lutjeharms and Gordon 1987), the transport around which was 40 Sv while an older Agulhas ring farther to the northwest carried 35 Sv (Gordon et al. 1987). Shoreward of detatched Agulhas rings in the source region of the Benguela Current, estimates of the net northward transports, or "leakage," of Indian Ocean thermocline water into the South Atlantic have been made which range from 5 Sv (Harris and Van Foreest 1978) to 10-14 Sv (Gordon et al. 1987; Gordon 1985). Although this interocean transfer of thermocline water is postulated to be an important part of the global circulation (Gordon 1986), it is not clear whether these transport values represent a quasi-steady flux of Indian Ocean water into the Benguela Current, or if the flux comes through episodic events.

In this study, we compute geostrophic transports of surface and intermediate waters, relative to different reference levels, in the open-ocean region north of the Agulhas Retroflection to the southern limits of the cyclonic gyre in the Angola Basin. We use five zonal lines of stations from $15^{\circ}$ to $32^{\circ} \mathrm{S}$, and close the region with a north-south line $1^{\circ}$ east of the Greenwich meridian. These six lines of stations are shown in Fig. 1. Except for the stations occupied by Meteor along $28^{\circ} \mathrm{S}$, all data used here are archived at the World Oceanographic Data Center in Washington, DC.

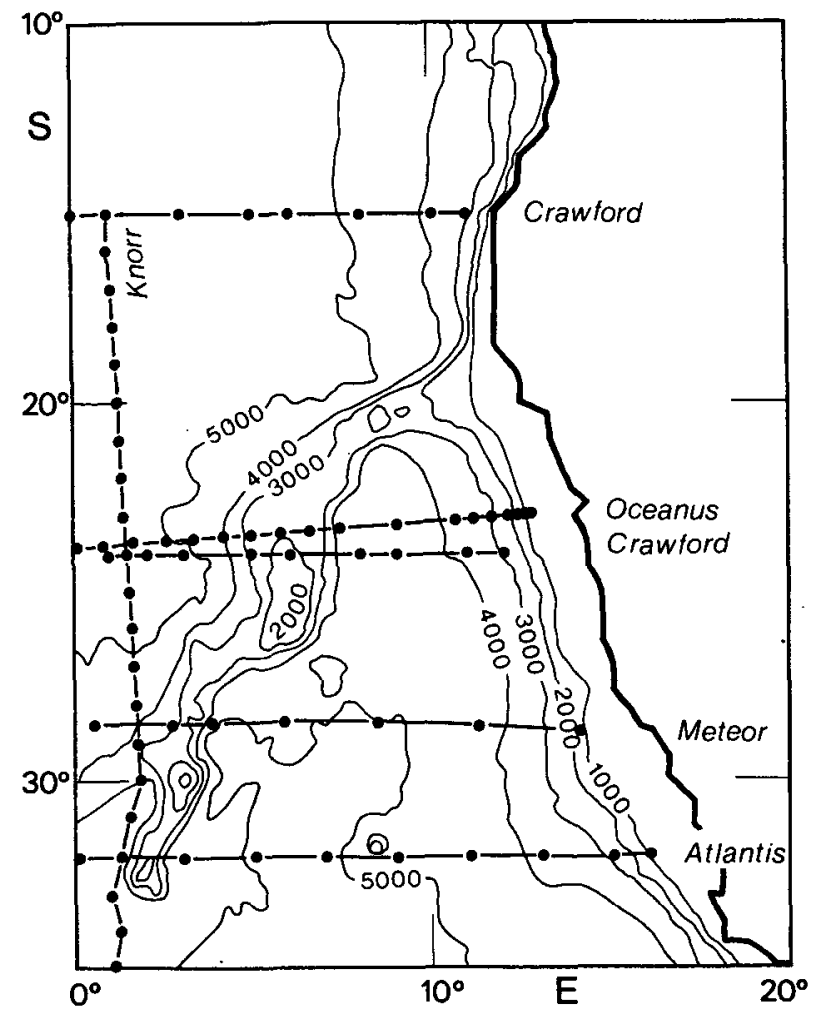

FIG. 1. Positions of hydrographic stations used here together with bottom bathymetry $(\mathrm{m})$. 


\section{Geostrophic computations}

A synopsis of the water mass structure in the upper $2000 \mathrm{~m}$ of the Benguela Current region is shown here with vertical sections along two lines: a north-south section of salinity (Fig. 2, from R/V Knorr along $1^{\circ} \mathrm{E}$ ) and zonal sections of temperature, salinity and oxygen (Fig. 3, from R/V Atlantis along $32^{\circ} \mathrm{S}$ ). Relative extrema in these properties are traced closely along isopycnals, thus leading to discontinuities. In the meridional section (Fig. 2), the relatively fresh core of Antarctic Intermediate Water (AAIW) is seen to form a nearly continuous layer that becomes shallower and saltier toward its northern end, the higher-latitude freshness being indicative of a southern source. This salinity minimum, in both Figs. 2 and 3, lies within the isopycnal range of $\sigma_{0}=27.2-27.3 \mathrm{~kg} \mathrm{~m}^{-3}$, which is slightly beneath the AAIW oxygen maximum lying in the range of $\sigma_{0}=27.15-27.25 \mathrm{~kg} \mathrm{~m}^{-3}$. In Fig. 3, there are strong inversions in the oxygen field in the layer between the surface and the maximum associated with AAIW, a layer where an admixture of central waters from the Indian and Atlantic Oceans, together with water from the subantarctic, spread northward into the South Atlantic (Gordon et al. 1987). Beneath the AAIW maximum, the oxygen field becomes considerably smoother; the minimum associated with the upper branch of Circumpolar Deep Water (CDW) is almost continuous near $\sigma_{0}=27.6 \mathrm{~kg} \mathrm{~m}^{-3}$. In sections farther north (not shown), the values of this minimum increase, indicating a southern source for this layer as well.

Participating in the anticyclonic circulation of the South Atlantic subtropical gyre is the AAIW (Buscaglia 1971). In the western basin, this anticyclonic shear may extend to $3500 \mathrm{~m}$ depth (Reid et al. 1977), thus including the upper branch of CDW as well as the underlying North Atlantic Deep Water (NADW). Whether such great depths for zero velocity obtain in the eastern basin, north of the deep-reaching Antarctic Circumpolar Current, is not clear. Reference levels obtained on the basis of zero or weak vertical gradients in geopotential anomaly in this region lie near $900 \mathrm{~m}$ depth at $15^{\circ} \mathrm{S}$, descending to $1400 \mathrm{~m}$ off Cape Town (Defant, 1941). These depths are generally between the cores of AAIW and the underlying CDW, but not along any particular isopycnal. It is likely, however, that transport values obtained from using such reference levels are underestimated in light of the weakening signature of the upper CDW toward the north.

Here we assume that at least the AAIW and the upper branch of CDW flow in the same direction as the surface layer. To obtain upper limits to the transports in the surface and intermediate layers, we also consider the unlikely case where the bottom flow vanishes. This is unlikely owing to evidence for cyclonic flow at abyssal depths in the Cape Basin (Reid 1988), flow which must be accompanied by a deep reversal somewhere beneath the Benguela Current. For the following computations, we take as the lower boundary to surface water the

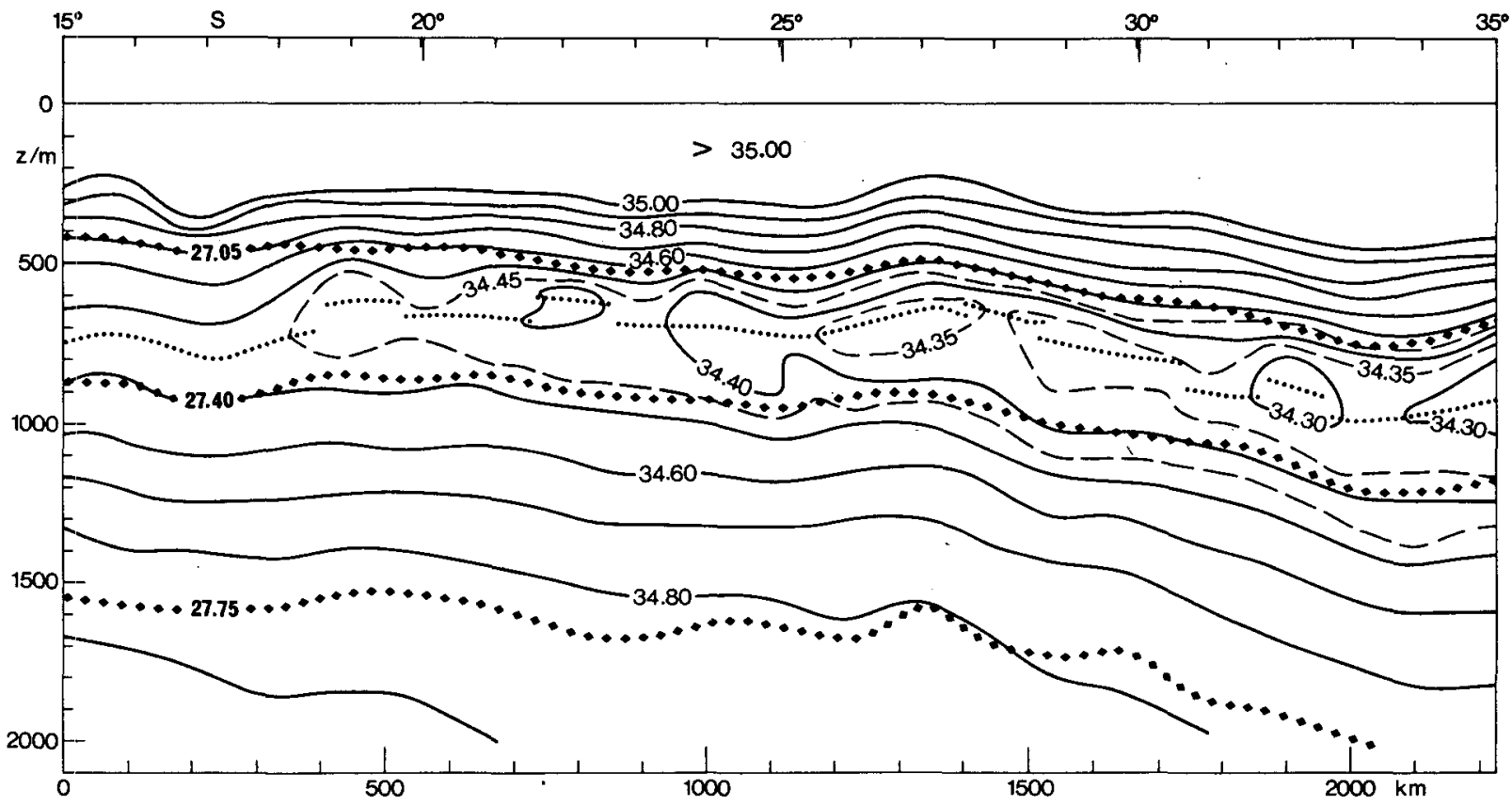

FIG. 2. Vertical distribution of salinity in the upper $2000 \mathrm{~m}$ along the north (left)-south (right) line of stations occupied by R/V Knorr near $1^{\circ} \mathrm{E}$. Relative minima in the Antarctic Intermediate Water are denoted by dots. Also shown are the isopycnals of $\sigma_{0}=27.05,27.4$, and $27.75 \mathrm{~kg} \mathrm{~m}^{-3}$ (diamonds). 

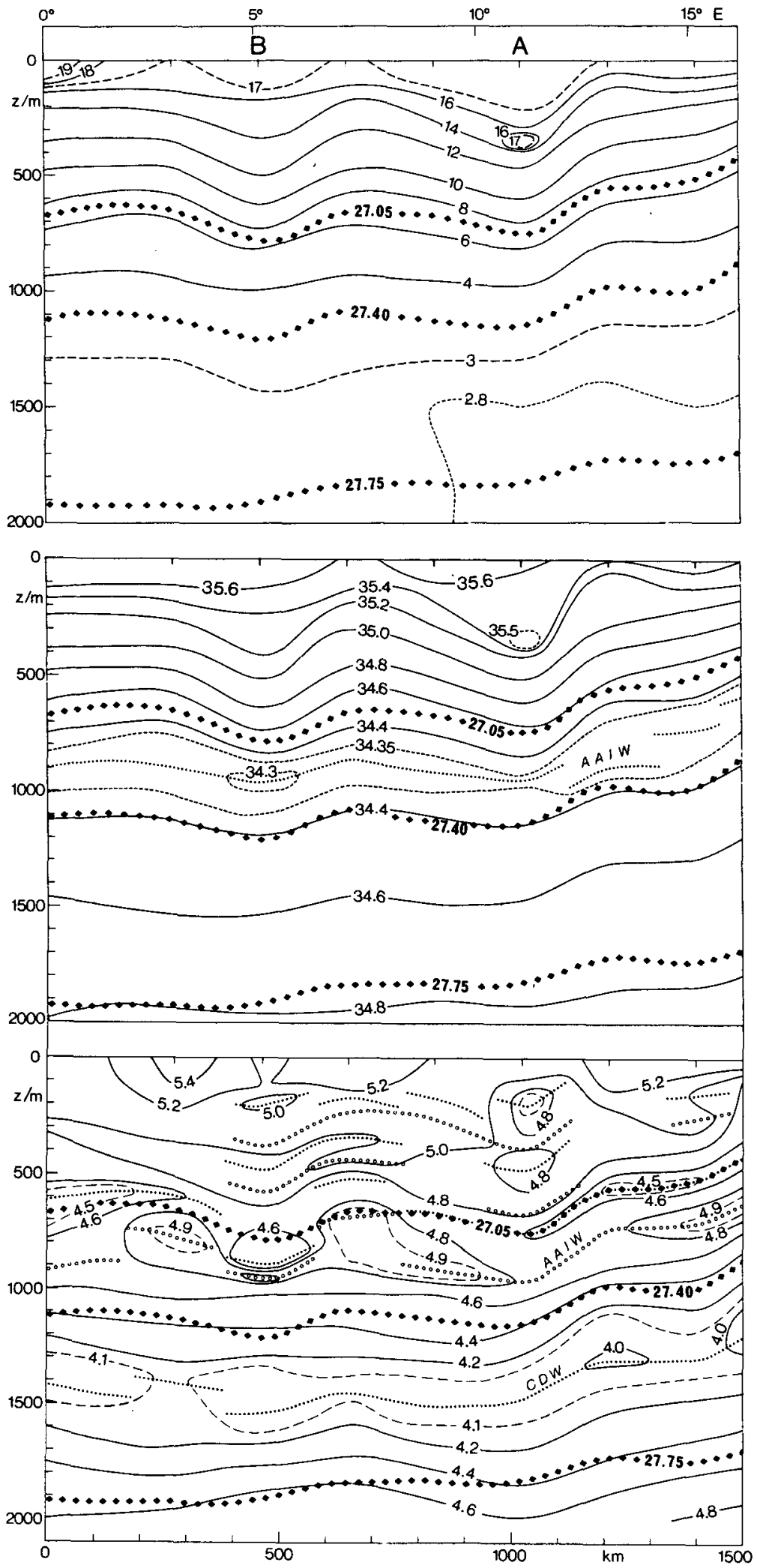

Fig. 3. Vertical distributions of temperature in ${ }^{\circ} \mathrm{C}$ (top), salinity (middle), and oxygen in $\mathrm{ml}^{-1}$ (bottom) in the upper $2000 \mathrm{~m}$ along the west (left)-east (right) line of stations occupied by R/V Atlantis near $32^{\circ} \mathrm{S}$. Relative maxima are denoted by open circles and minima by dots. Also shown are the isopycnals of $\sigma_{0}=27.05,27.4$, and $27.75 \mathrm{~kg} \mathrm{~m}^{-3}$ (diamonds). 
isopycnal $\sigma_{0}=27.05 \mathrm{~kg} \mathrm{~m}^{-3}$, which has a depth range of 400-700 m. Lying at depths of $850-1200 \mathrm{~m}$, between the AAIW and upper branch of CDW, is $\sigma_{0}$ $=27.4 \mathrm{~kg} \mathrm{~m}^{-3}$. Between the upper branch of CDW and NADW, at depths of $1500-2000 \mathrm{~m}$, is $\sigma_{0}=27.75$ $\mathrm{kg} \mathrm{m}^{-3}$ (near $\sigma_{2}=36.9 \mathrm{~kg} \mathrm{~m}^{-3}$ ). These isopycnals are included in Figs. 2 and 3. For the purposes of comparison, the latter two density surfaces, and the ocean bottom, are used as our reference levels for calculating the geostrophic transports of surface and intermediate waters. The actual values of transports in the upper layers are considered to lie somewhere between those obtained by using the base of the upper CDW as reference and those obtained by referencing the ocean bottom. Differences between the two are generally small.

Summarized in Table 1 are the northward geostrophic transports of surface and intermediate waters across the zonal lines of stations in Fig. 1 using the three different reference levels. The values are given as summations over the lengths of those lines, except for the values in parentheses which pertain only to the current band proper, i.e., the current band contained in the region between the eastern boundary and the nearest point of vanishing northward flow. The meaning of this can be seen in Fig. 4, which shows the field of geostrophic transport in the surface layer constructed by using $\sigma_{0}=27.75 \mathrm{~kg} \mathrm{~m}^{-3}$ as the reference level.

This method, enclosing an area with nonsynoptic sections, is normally not used for computing a geostrophic transport field. In regions of strong, deepreaching seasonal variability, such as the western Indian Ocean, this procedure leaves imbalances (Lutjeharms 1972); or, imbalances among nonsynoptic sections might result in areas of pronounced mesoscale activity, such as near the Agulhas Retroflection, or in areas having interannual variability. The southern end of our region is near the Agulhas Retroflection, and evidence points to a pair of Agulhas rings influencing our geo- strophic calculations. However, this does not seem to lead to any serious imbalance as we will discuss further. Regarding interannual variability, the region off southwestern Africa is known to experience warm and cool periods, but only three major warm events comparable to a Pacific El Niño have been documented, those coming in the years 1934, 1963, and 1984 (Shannon et al. 1986). None of our zonal sections were made in those years (Table 1), and neither was the north-south section by the Knorr (October 1983). Inspection of Fig. 4 in Taunton-Clark and Shannon (1988), though, reveals that the 1925 Meteor section at $28^{\circ} \mathrm{S}$ and the 1957 Crawford section at $15^{\circ} \mathrm{S}$ were made during periods of relative cool, with sea surface temperatures in the appropriate regions being about a degree less than normal. Conversely, the 1983 Oceanus section at $23^{\circ} \mathrm{S}$ and the 1983 Knorr section along the $1^{\circ} \mathrm{E}$ were made during a relatively warm period of similar magnitude, whereas the remaining two surveys were conducted during near normal conditions. These departures from normal are smaller than the seasonal variability of mixed layer temperature, which in another eastern boundary region, near the Azores Current, appears to have negligible influence on baroclinic transport (Stramma and Isemer 1988).

Also of potential importance to our calculations is the upwelling regime along the southwestern coast of Africa. The highly variable frontal jets on the shelf there may produce transports as high as $7 \mathrm{~Sv}$ (Bang and Andrews 1974), whereas upwelling filaments may extend anywhere from 50 to $600 \mathrm{~km}$ seaward of the coast (Lutjeharms and Stockton 1987) and could bias our transport calculations. However, as with the preceeding problems, neither of these associated with coastal upwelling appear to cause any serious imbalance in our transport field. In Fig. 4, the Knorr section along $1^{\circ} \mathrm{E}$ yields a westward transport between $15^{\circ}$ and $24^{\circ} \mathrm{S}$ that is only $1 \mathrm{~Sv}$ larger than accounted for by the zonal sections, whereas the imbalance between $24^{\circ}$ and $32^{\circ} \mathrm{S}$

TABLIE 1. Northward geostrophic transport (Sv) of surface water (SW) and Antarctic Intermediate Water (AAIW) by the Benguela Current between the Greenwich meridian and the continental shelf of Africa from historical hydrographic data. At stations pairs near the shelf and not deep enough to reach the indicated reference, the deepest depths common to the stations are used. For reference at the bottom, the deepest common depths are also used. Values in parentheses, where applicable, represent transports between the shelf and the western side of the Benguela Current (where the northward flow vanishes).

\begin{tabular}{|c|c|c|c|c|c|c|c|c|c|c|}
\hline \multirow[b]{2}{*}{ Reference } & \multicolumn{2}{|c|}{$\begin{array}{c}\text { Crawford } \\
15^{\circ} \mathrm{S} \\
\text { Apr } 1957\end{array}$} & \multicolumn{2}{|c|}{$\begin{array}{c}\text { Oceanus } \\
23^{\circ} \mathrm{S} \\
\mathrm{Mar} 1983\end{array}$} & \multicolumn{2}{|c|}{$\begin{array}{l}\text { Crawford } \\
24^{\circ} \mathrm{S} \\
\text { Oct } 1958\end{array}$} & \multicolumn{2}{|c|}{$\begin{array}{c}\text { Meteor } \\
28^{\circ} \mathrm{S} \\
\text { Aug } 1925\end{array}$} & \multicolumn{2}{|c|}{$\begin{array}{c}\text { Atlantis } \\
32^{\circ} \mathrm{S} \\
\text { May } 1959\end{array}$} \\
\hline & SW & AAIW & SW & AAIW & sW & AAIW & SW & AAIW & SW & AAIW \\
\hline$\sigma_{0}=27.4$ & 2.5 & 0.3 & $\begin{array}{c}8.3 \\
(11.2)\end{array}$ & $\begin{array}{c}0.7 \\
(1.2)\end{array}$ & 9.7 & 0.0 & $\begin{array}{c}18.6 \\
(13.9)\end{array}$ & $\begin{array}{c}2.6 \\
(2.4)\end{array}$ & $\begin{array}{c}16.3 \\
(25.8)\end{array}$ & $\begin{array}{c}2.9 \\
(3.4)\end{array}$ \\
\hline$\sigma_{0}=27.75$ & 0.6 & -2.1 & $\begin{array}{c}9.1 \\
(13.2)\end{array}$ & $\begin{array}{c}1.2 \\
(2.5)\end{array}$ & $\begin{array}{l}10.1 \\
(8.8)\end{array}$ & $\begin{array}{l}-1.0 \\
(0.4)\end{array}$ & $\begin{array}{c}22.9 \\
(17.8)\end{array}$ & $\begin{array}{c}5.7 \\
(5.4)\end{array}$ & $\begin{array}{l}20.4 \\
(29.9)\end{array}$ & $\begin{array}{c}5.3 \\
(6.0)\end{array}$ \\
\hline $\begin{array}{l}\text { Ocean } \\
\text { bottom }\end{array}$ & 1.5 & -1.2 & $\begin{array}{c}7.9 \\
(13.3)\end{array}$ & $\begin{array}{c}0.0 \\
(2.4)\end{array}$ & $\begin{array}{c}9.3 \\
(8.9)\end{array}$ & $\begin{array}{c}-0.2 \\
(0.0)\end{array}$ & $\begin{array}{c}27.7 \\
(22.6)\end{array}$ & $\begin{array}{l}9.5 \\
(9.0)\end{array}$ & $\begin{array}{c}26.8 \\
(31.9)\end{array}$ & $\begin{array}{l}10.0 \\
(7.6)\end{array}$ \\
\hline $\begin{array}{l}\text { Base of layer } \\
\text { (m) }\end{array}$ & $370-420$ & $890-930$ & $410-570$ & $890-980$ & $390-560$ & $860-940$ & $430-630$ & $920-1040$ & $390-730$ & $890-1180$ \\
\hline
\end{tabular}




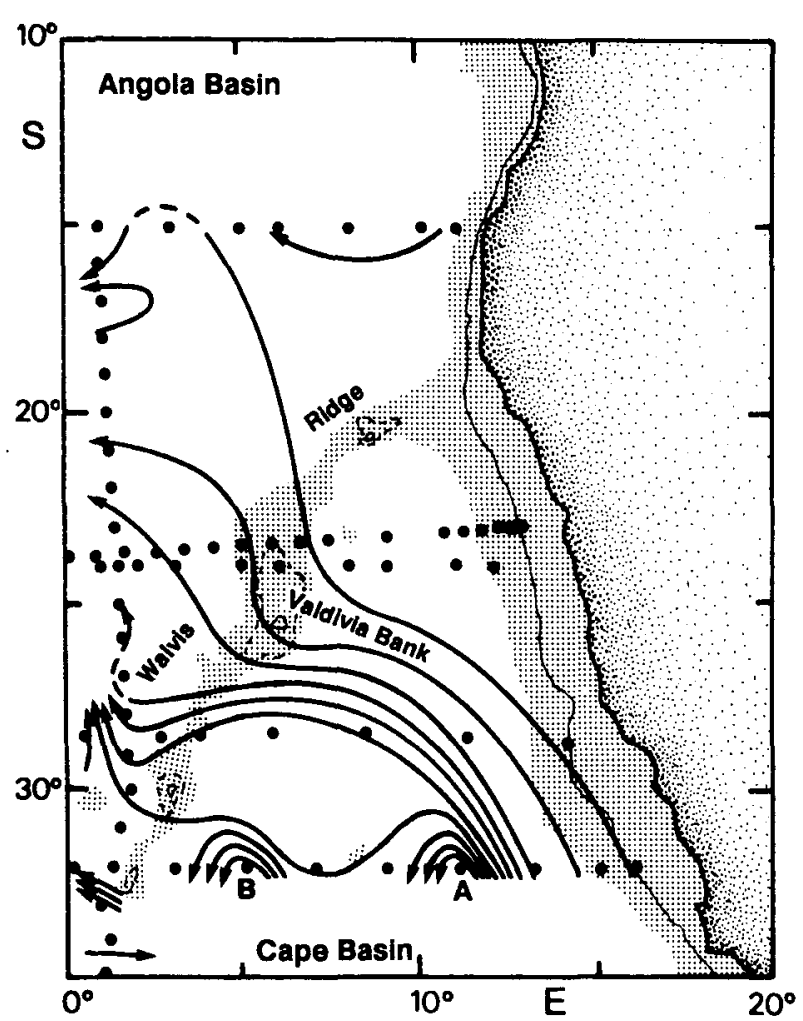

Fig. 4. Field of geostrophic transport of surface water (less dense than $\sigma_{0}=27.05 \mathrm{~kg} \mathrm{~m}^{-3}$ relative to the $\sigma_{0}=27.75 \mathrm{~kg} \mathrm{~m}^{-3}$ isopycnal (near $\sigma_{2}=36.9 \mathrm{~kg} \mathrm{~m}^{-3}$ ). Each flow line represents $3 \mathrm{~Sv}$. Also shown are the $1000-\mathrm{m}$ isobath (light line), selected $2000-\mathrm{m}$ isobaths (dashed lines), and areas less than $3000 \mathrm{~m}$ deep (shading).

is just $2 \mathrm{~Sv}$. These imbalances are unexpectedly small, possibly a reflection of how much transport is associated with coastal upwelling that we do not resolve with our deep stations. But being that these imbalances are less than the contour interval of $3 \mathrm{~Sv}$ leaves little need for making any adjustments. Furthermore, our transport field compares quite well in shape with that for the surface layer derived by Fu ( 1981 ) with inverse methods, with dynamic fields given by Reid et al. (1977) and Tsuchiya (1985), and with trajectories of drifting buoys (Harris and Shannon 1979; Patterson 1985; Piola et al. 1987).

In our Fig. 4, the Benguela Current is located near the eastern boundary at $32^{\circ} \mathrm{S}$ and has northward surface speeds of nearly $30 \mathrm{~cm} \mathrm{~s}^{-1}$ relative to $\sigma_{0}=27.75$ $\mathrm{kg} \mathrm{m}^{-3}$, speeds which probably would have been higher had the station spacing been less. According to Table 1 , the current band transports about $30 \mathrm{~Sv}$ of surface water and $6 \mathrm{~Sv}$ of AAIW northward across $32^{\circ} \mathrm{S}$; however, these values are probably not representative of the Benguela Current as roughly $9 \mathrm{~Sv}$ of surface water and nearly $2 \mathrm{~Sv}$ of AAIW are returned to the south near $10^{\circ} \mathrm{E}$, the southward return likely resulting from an Agulhas ring sitting on the western side of the Ben- guela Current. Referring to Fig. 4, there are two anticyclonic features on the line of stations at $32^{\circ} \mathrm{S}$, these being observed at the stations we call $\mathrm{A}$ and $\mathrm{B}$. According to the property distributions in Fig. 3, both of these appear to be of Agulhas Current origin.

Rings shed from the Agulhas Retroflection into the South Atlantic are relatively warm and salty, but their signatures in the oxygen field may depend on season. Using data from the vicinity of the Agulhas Retroflection during an austral spring, Gordon et al. (1987) observed a pair of Agulhas rings to be relatively well oxygenated due to winter alteration. However, our $\mathrm{At}$ lantis section at $32^{\circ} \mathrm{S}$ was made in the austral fall and prior to the onset of aeration by winter convection. (An anonymous reviewer has pointed out that some of the structure in this oxygen section might be due to noisy data from the IGY work of Atlantis, but that the overall patterns are probably correct.) As seen in Fig. 3 , both anticyclonic features have oxygen deficits, particularly the one at station A. Oxygen concentrations there dip to less than $4.7 \mathrm{ml} \mathrm{l}^{-1}$ near $200 \mathrm{~m}$ depth, while at $B$ they are under $5 \mathrm{ml}^{-1}$ at the same level. These low oxygen signatures extend down to the AAIW layer and likely come from the thermocline and intermediate waters of the western Indian Ocean. Vertical sections of oxygen from the Indian Ocean (Wyrtki et al. 1971 ) show a low oxygen tongue centered at depths of 100-200 m extending southward from the coast of Somalia to the southern end of Africa. This layer of oxygen deficiency has values of less than $5 \mathrm{ml} \mathrm{l}^{-1}$ in the region of the Agulhas Retroflection, values very similar to those observed in the anticyclonic cells in Fig. 4 at $32^{\circ} \mathrm{S}$. At greater depth, in the AAIW layer on the $\sigma_{t}=27.25 \mathrm{~kg} \mathrm{~m}^{-3}$ isopycnal, low oxygen levels as well as relatively high temperatures and salinities are introduced into the region of retroflection by the Agulhas Current (Shannon and Hunter 1988). Rings shed from the Agulhas Current should therefore be identifiable in the southeastern Atlantic as warm, salty, and oxygen-poor (summer) features from the surface down to the AAIW, and this appears to be the case at stations $A$ and $B$ in Fig. 3. Unfortunately, because we are not using a synoptic dataset, and because of the very large station spacing at the southern end of our region (on the order of $200 \mathrm{~km}$ ), we are unable to provide an estimate of how much Indian Ocean water is introduced into the South Atlantic.

Because the upper-level water at stations A and B likely originated from the Agulhas Current, the southward flows to the west of each of these stations (Fig. 4) are interpreted as belonging to return flows around mesoscale eddies. The net northward transport of surface water by the Benguela Current is thus nearer to $21 \mathrm{~Sv}$, while that for AAIW is only about 4-5 Sv. According to Table 1, the northward transports of the current band increase with increasingly deep reference levels, which is consistent with the presence of an abys- 
sal cyclonic circulation in the Cape Basin (Reid 1988). The difference between transport values of surface water by the current band using reference levels at the base of the upper branch of CDW and at the ocean bottom differ by only $2 \mathrm{~Sv}$, suggesting that the actual geostrophic transport in the surface layer at this location is quite near $21 \mathrm{~Sv}$.

Upon crossing $32^{\circ} \mathrm{S}$, the Benguela Current begins to separate from the eastern boundary and branches out into a considerably broader and more complex flow. 'The eddy field and meridional shifts in the axis of the subtropical gyre have probable influence in the appearance of this branching among our nonsynoptic sections; however, the relation between bottom topography and the transport field suggests that it is real. Similar branching is well documented in the gyre circulation of the subtropical North Atlantic. Here, a small component of the surface flow, about $3 \mathrm{~Sv}$, moves off toward the west around the northern sides of the two anticyclonic features whereas the remainder of the current flows toward the northwest.

The northwestward branch crosses $28^{\circ} \mathrm{S}$ carrying about $18 \mathrm{~Sv}$ of surface water, beneath which flow 4 to $5 \mathrm{~Sv}$ of AAIW. Here again, the transport values increase with increasingly deep reference levels as would be expected with southward abyssal flow at the eastern boundary. Near $28^{\circ} \mathrm{S}$, the Benguela Current turns sharply toward the west, evidently under the influence of the Walvis Ridge. In the middle portions of this ridge is the $300-\mathrm{km}$ long Valdivia Bank, an obstacle shallower than $2000 \mathrm{~m}$ with local features rising to within $300 \mathrm{~m}$ of the sea surface. This portion of the Benguela Current is observed to flow largely to the south of the Valdivia Bank and across a relatively deep segment of the Walvis Ridge, whereupon a bifurcation of the flow is indicated.

Farther north, at $23^{\circ}-24^{\circ} \mathrm{S}$, the flow continues to fan out. The Oceanus and Crawford sections here are very near one another but are nonsynoptic, so complete agreement between them is not expected. However, these two sections do have much in common. According to Table 1, the transport values here are nearly independent of reference depth; essentially all the vertical shear is in the surface layer. And, as shown in Fig. 4 , there is a region that is more than $600 \mathrm{~km}$ wide next to the continental shelf having very sluggish flow, a result of the more southerly separation of the Benguela Current from the eastern boundary. This weak northward flow in the northern Cape Basin sums to slightly more than $3 \mathrm{~Sv}$ in the surface layer and must pass over the Walvis Ridge north of the Valdivia Bank into the Angola Basin. In both of these sections the bulk of the Benguela Current is found west of the Valdivia Bank. The northward transport of surface water in the current band, as we have defined it (Table 1), is about $13 \mathrm{~Sv}$ in the Oceanus section, $4 \mathrm{~Sv}$ more than in the Crawford line. The contours in Fig. 4 represent an average be- tween these two sections. Beneath the surface layer, the northward transport of AAIW by the current band is weak in each section, averaging to just over $1 \mathrm{~Sv}$. With respect to total northward transport across these two lines, the difference in the surface layer is only a sverdrup or so about a mean value near $10 \mathrm{~Sv}$, with practically no northward transport of AAIW underneath. Therefore, virtually all of the AAIW transported north across $32^{\circ} \mathrm{S}$ turns west and crosses the Greenwich meridian before reaching $23^{\circ}-24^{\circ} \mathrm{S}$, which agrees well with a $5.6 \mathrm{~Sv}$ westward transport of AAIW across the Knorr section south of $24^{\circ} \mathrm{S}$. This also compares well with the schematic representation of flow in the AAIW layer near southern Africa given by Shannon and Hunter (1988, their Fig. 8).

Shown in Fig. 5 is the distribution of northward velocity in the upper $800 \mathrm{~m}$, relative to $\sigma_{0}=27.75 \mathrm{~kg}$ $\mathrm{m}^{-3}$, along the Oceanus section at $23^{\circ} \mathrm{S}$. Near the coast there is a current core with surface velocities exceeding $15 \mathrm{~cm} \mathrm{~s}^{-1}$ toward the north, a core that is restricted to the upper $100 \mathrm{~m}$ and is probably due to upwelling. It accounts for only $0.4 \mathrm{~Sv}$ of transport in the surface layer. East of this shallow current at the shelf edge is the wide region of sluggish flow, which ends at the western side of the Walvis Ridge near $5^{\circ}-6^{\circ} \mathrm{E}$. Next to the western side of the ridge is a narrow surface current having northward speeds of about $10 \mathrm{~cm} \mathrm{~s}^{-1}$. The spatial patterns in Fig. 4 suggest that this core is flowing along the bathymetry of the Valdivia Bank. About $300 \mathrm{~km}$ farther west, at $1.5^{\circ}-3^{\circ} \mathrm{E}$, a stronger current core is found which has northward surface speeds in excess of $20 \mathrm{~cm} \mathrm{~s}^{-1}$. There is no southward flow between these surface currents; they are therefore not a part of a single, meandered flow, but are separate features. The distinct identity of these two cores might not be persistent, however. The velocity field from the Crawford section at $24^{\circ} \mathrm{S}$ (not shown) shows a broader and slower current, one that would be obtained with a section made at a grazing angle to the flow. It is possible that the seaward extension of this part of the Benguela Current was located farther south during the Crawford survey than it was during the Oceanus, and that two cores within it did not exist during the Crawford cruise.

Referring again to Fig. 4, the weak transport of surface water in the northern Cape Basin is that which comes into contact with the southern limb of a cyclonic gyre in the Angola Basin. A shallow front, well marked in just the upper $50 \mathrm{~m}$, develops there and has been described by Shannon et al. (1987). The wide station spacing of the Crawford section along $15^{\circ} \mathrm{S}$ does not resolve this front well; the surface flow is directed mainly toward the west and there is very little meridional shear anywhere underneath. Being that the principal seaward extensions of the Benguela Current system are well to the south of this line, there are no deepreaching interactions observed between the Benguela 


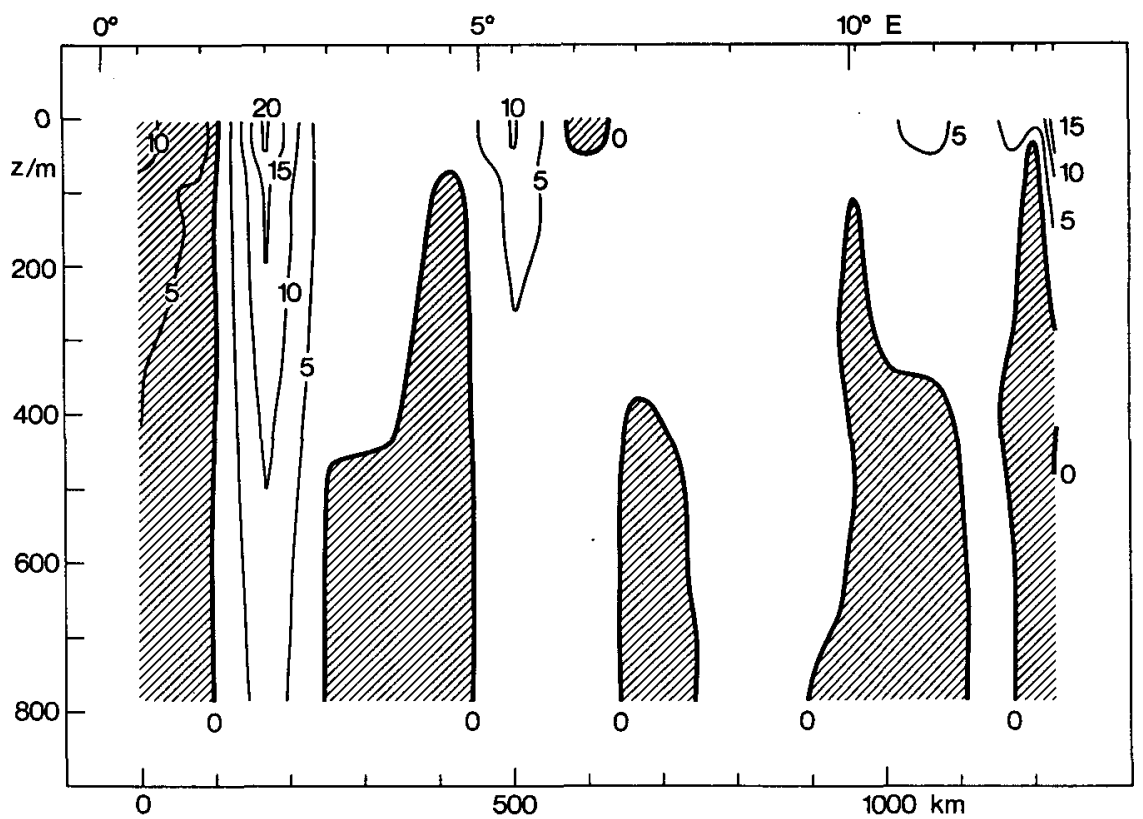

FIG. 5. Vertical distribution of northward geostrophic velocity $\left(\mathrm{cm} \mathrm{s}^{-1}\right)$ in the upper $800 \mathrm{~m}$ relative to the isopycnal $s$. fface of $\sigma_{0}=27.75 \mathrm{~kg} \mathrm{~m}^{-3}$ (near $\sigma_{2}=36.9 \mathrm{~kg} \mathrm{~m}^{-3}$ ) along the west (left)-east (right) line of iations occupied by R/V Oceanus near $23^{\circ} \mathrm{S}$. Shading denotes southward flow. Tick-marks along the top are at midpoints between stations.

Current and the cyclonic gyre in the Angola Basin east of the Greenwich meridian.

\section{Summary}

Although a considerable number of investigations have been conducted in the upwelling region off the southwestern coast of Africa, there have been very few open-ocean estimates made of the Benguela Current transport. In this study, we use historical data from the area south of the cyclonic gyre in the Angola Basin and north of the Agulhas Retroflection, all east of the Greenwich meridian, to calculate open-ocean geostrophic transports in the surface and intermediate layers.

Using an isopycnal surface between the upper branch of Circumpolar Deep Water and North Atlantic Deep Water as our reference level $\left(\sigma_{0}=27.75 \mathrm{~kg} \mathrm{~m}^{-3}\right.$, or near $\left.\sigma_{2}=36.9 \mathrm{~kg} \mathrm{~m}^{-3}\right)$, we obtain a northward surface layer transport of about $30 \mathrm{~Sv}$ crossing $32^{\circ} \mathrm{S}$ near the eastern boundary. These $30 \mathrm{~Sv}$ are composed of $21 \mathrm{~Sv}$ belonging to the Benguela Current and $9 \mathrm{~Sv}$ recirculating in an anticyclonic feature on the western side of the Benguela Current. This anticyclonic feature, along with another one farther west, probably originated from the Agulhas Current Retroflection. A small portion of the Benguela Current, about $3 \mathrm{~Sv}$, turns sharply toward the west to flow around the northern sides of the anticyclonic pair. After crossing $32^{\circ} \mathrm{S}$, the bulk of the Benguela Current flows northwestward, carrying about
$18 \mathrm{~Sv}$ of surface water across $28^{\circ} \mathrm{S}$. Further branching is indicated there. Most of the current turns directly toward the west to flow over a relatively deep segment of the Walvis Ridge south of the Valdivia Bank, leaving about $3 \mathrm{~Sv}$ to drift northward through the northern end of the Cape Basin. A northward surface current of about $10 \mathrm{~cm} \mathrm{~s}^{-1}$ is found at the western side of the Valdivia Bank, likely guided by regional bathymetry. Another northward current core, not connected with the preceding one, is found $300 \mathrm{~km}$ farther west with surface speeds exceeding $20 \mathrm{~cm} \mathrm{~s}^{-1}$. At $15^{\circ} \mathrm{S}$, the surface layer flows mainly toward the west, and because the principal seaward extensions of the Benguela Current are found well to the south there are no deep-reaching interactions seen between this current and the cyclonic gyre in the Angola Basin. With respect to the Antarctic Intermediate Water, about 4-5 Sv are observed to flow northward with the Benguela Current across $32^{\circ}$ and $28^{\circ} \mathrm{S}$, essentially all of which turns to the west to cross the Greenwich meridian south of $24^{\circ} \mathrm{S}$.

Acknowledgments. This work has been supported by the Bundesminister für Forschung und Technologie Grant 07KF2128-12a, Federal Republic of Germany, Bonn.

\section{REFERENCES}

Bang, N. D., and W. R. H. Andrews, 1974: Direct current measurements of a shelf-edge frontal jet in the Southern Benguela system. J. Mar. Res., 32, 405-417. 
Berghaus, Hein., 1852: Physikalischer Atlas, erster Band, zweite Auflage, Gotha, 72 pp., 52 plates.

Berghaus, Herm., 1867: Welt-Karte zur Übersicht der Meeres-Strömungen und des Schnellverkehrs. Handatlas über alle Theile der Erde und über das Weltgebäude, A. Stieler, Ed., Gotha, 95 charts.

Buchan, A., 1895: Report on oceanic circulation, based on the observations made on board H.M.S. Challenger, and other observations. Report on the scientific results of the voyage of H.M.S. Challenger during the years 1873-1876. A summary of the scientific results. Second Part: Appendix, 38 pp., 16 plates.

Buscaglia, J. L., 1971: On the circulation of the intermediate water in the southwestern Atlantic Ocean. J. Mar. Res., 29, 245-255.

Chapman, P., and L. V. Shannon, 1985: The Benguela ecosystem. 2. Chemistry and related processes. Oceanography and Marine Biology, An Annual Review, 23, M. Barnes, Ed., Aberdeen University Press, 183-251.

Darbyshire, M., 1963: Computed surface currents off the Cape of Good Hope. Deep-Sea Res., 10, 623-632.

Defant, A., 1941: Die absolute Topographie des physikalischen Meeresniveaus und der Druckflächen sowie der Wasserbewegungen des Atlantischen Ozeans. Wiss. Ergebn. deutsch. Atlant. Exped. auf dem Forschungs- und Vermessungsschiff Meteor 1925-1927. 6, Teil 2, 5. Lfg, 191-260.

Fu, L.-L., 1981: The general circulation and meridional heat transport of the subtropical South Atlantic determined by inverse methods. J. Phys. Oceanogr., 11, 1171-1193.

Gordon, A. L., 1985: Indian-Atlantic transfer of thermocline water at the Agulhas Retroflection. Science, 227, 1030-1033.

- 1986: Interocean exchange of thermocline water. J. Geophys. Res., 91, 5037-5046.

- - and W. Haxby, 1988: Agulhas eddies: An altimeter view (abstract). SAARI Meeting Report, May 24-26, 1988, LamontDoherty Geol. Observ. of Columbia University, Palisades, NY, 2-3.

__, J. R. E. Lutjeharms and M. L. Gründlingh, 1987: Stratification and circulation at the Agulhas retroflection. Deep-Sea Res., 34, $56.5-599$.

Harris, T. F. W., and D. Van Foreest, 1978: The Agulhas Current in March 1969. Deep-Sea Res., 25, 549-561.

- and L. V. Shannon, 1979: Satellite-tracked drifter in the Benguela Current system. S. Afr. J. Sci., 75, 316-317.

Hart, T. J., and R. I. Currie, 1960: The Benguela Current. Discovery Reports, 31, 123-298.

Krümmel, O., 1882: Bemerkungen über die Meeresströmungen und Temperaturen in der Falklandsee. Aus dem Archiv der Deutschen Seewarte, V, Hamburg, Nr. 2, 25 pp.

Lutjeharms, J. R. E., 1972: A quantitative assessment of year-to-year variability in water movement in the south-west Indian Ocean. Nat. Phys. Sci., 239, 59-60.

at sea. Nature, 325, 138-140.

- , and P. L. Stockton, 1987: Kinematics of the upwelling front off southern Africa. S. Afr. J, Mar. Sci., 5, 35-49.

- , and H. R. Valentine, 1987: Water types and volumetric considerations of the south-east Atlantic upwelling regime. S. Afr. J. Mar. Sci., 5, 63-71.

- and R. C. van Ballegooyen, 1988: The retroflection of the Agulhas Current. J. Phys. Oceanogr., 18, 1570-1583.

Moroshkin, K. V., V. A. Bubnov and R. P. Bulatov, 1970: Water circulation in the eastern South Atlantic Ocean. Oceanology, $10(1), 27-34$.

Nelson, G., and L. Hutchings, 1983: The Benguela upwelling area. Progress in Oceanography, Vol. 12, Pergamon, 333-356.

Patterson, S. L., 1985: Surface circulation and kinetic energy distri- butions in the Southern Hemisphere oceans from FGGE drifting buoys. J. Phys. Oceanogr., 15, 865-884.

Petermann, A., 1865: Der Nordpol und Südpol, die Wichtigkeit ihrer Erforschung in geographischer und kulturhistorischer Beziehung mit Bemerkungen über die Strömungen der Polar-Meere. $P e$ termann's Geographische Mittheilungen, Gotha, 146-160, Karte 5 .

Piola, A. R., H. A. Figueroa and A. A. Bianchi, 1987: Some aspects of the surface circulation south of $20^{\circ} \mathrm{S}$ revealed by First GARP Global Experiment drifters. J. Geophys. Res., 92, 5101-5114.

Reid, J. L., 1988: Top-to-bottom total geostrophic circulation of the South Atlantic Ocean (abstract). SAARI Meeting Report, May 24-26, 1988, Lamont-Doherty Geol. Observ. of Columbia University, Palisades, NY, 1 pp.

, W. D. Nowlin, Jr. and W. C. Patzert, 1977: On the characteristics and circulation of the southwestern Atlantic Ocean. $J$. Phys. Oceanogr., 7, 62-91.

Rennell, J., 1832: An investigation of the currents of the Atlantic Ocean, and of those which prevail between the Indian Ocean and the Atlantic. London, $359 \mathrm{pp}$.

Schott, G., 1902: Die Auftriebszone an der Küste von Südafrika. Wiss. Ergebn. der Dtsch. Tiefsee-Exped. Valdivia 1898-1899. Vol. 1. 124-128.

Shannon, L. V., 1966: Hydrology of the south and west coasts of South Africa. Invest. Rep. Div. Sea Fish., S. Afr., 58, 52 pp.

- , 1985: Description of the Ocean Colour and Upwelling Experiment. South African Ocean Colour and Upwelling Experiment, L. V. Shannon, Ed., Sea Fisheries Research Institute, 1-12.

, and M. van Rijswijck, 1969: Physical oceanography of the Walvis Ridge region, Invest. Rep. Div. Sea Fish., S. Afr., 70, $19 \mathrm{pp}$.

- , and D. Hunter, 1988: Notes on Antarctic Intermediate Water around southern Africa. S. Afr. J. Mar. Sci., 6, 107-117.

- A. J. Boyd, G. B. Brundrit and J. Taunton-Clark, 1986: On the existence of an El Niño-type phenomenon in the Benguela System. J. Mar. Res., 44, 495-520.

- J. J. Agenbag and M. E. L. Buys, 1987: Large- and mesoscale features of the Angola-Benguela Front. S. Afr. J. Mar. Sci., 5, 11-34.

Stander, G. H., 1964: The Benguela Current off South West Africa. Invest. Rep. Mar. Res. Lab. S.W. Afr., 2, 43 pp.

Stramma, L., and H.-J. Isemer, 1988: Seasonal variability of meridional temperature fluxes in the eastern North Atlantic Ocean. J. Mar. Res., 46, 281-299.

Sverdrup, H. U., M. W. Johnson and R. H. Fleming, 1942: The Oceans: Prentice Hall, 1087 pp.

Taunton-Clark, J., and L. V. Shannon, 1988: Annual and interannual variability in the south-east Atlantic during the 20th century. S. Afr. J. Mar. Sci., 6, 97-106.

Tsuchiya, M., 1985: Evidence of a double-cell subtropical gyre in the South Atlantic Ocean. J. Mar. Res., 43, 57-65.

Veronis, G., 1973: Model of World Ocean circulation: I. Wind-driven, two-layer. J. Mar. Res., 31, 228-288.

Witte, E., 1880: Das Emporquellen von kaltem Wasser an meridionalen Küsten. Ann. Hydrogr. Mar. Meteor., 8, 192-193.

Wooster, W. S., and J. L. Reid, Jr., 1963: Eastern boundary currents. The Sea. Vol. 2, M. N. Hill, Ed., Wiley-Interscience, 253-280.

Wüst, G., 1957: Stromgeschwindigkeiten und Strommengen in den Tiefen des Atlantischen Ozeans. Wiss. Ergebn. deutsch. Atlant. Exped. auf dem Forschungs- und Vermessungsschiff Meteor 1925-1927. 6, Teil 2, 6. Lfg, 261-420.

Wyrtki, K., E. B. Bennett and D. J. Rochford, 1971: Oceanographic Atlas of the International Indian Ocean Expedition. National Science Foundation, Washington, DC, 531 pp. 